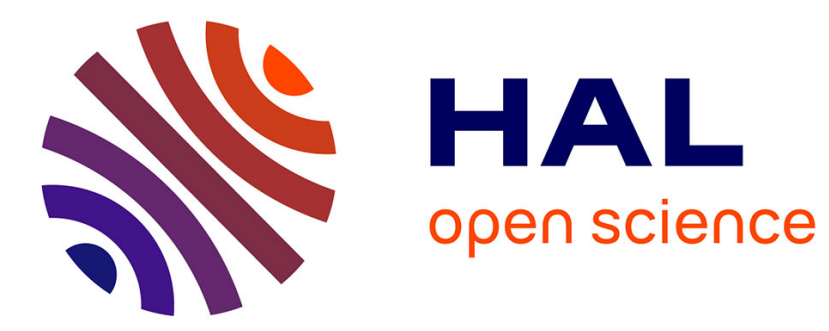

\title{
Automotive supplier parks: An imperative for build-to-order?
}

Mickey Howard, Joe Miemczyk, Andrew Graves

\section{To cite this version:}

Mickey Howard, Joe Miemczyk, Andrew Graves. Automotive supplier parks: An imperative for build-to-order?. European Journal of Purchasing and Supply Management, 2006, 12 (2), pp.91-104. 10.1016/j.pursup.2006.05.001 . hal-01118772

\section{HAL Id: hal-01118772 \\ https://hal-audencia.archives-ouvertes.fr/hal-01118772}

Submitted on 23 Feb 2015

HAL is a multi-disciplinary open access archive for the deposit and dissemination of scientific research documents, whether they are published or not. The documents may come from teaching and research institutions in France or abroad, or from public or private research centers.
L'archive ouverte pluridisciplinaire HAL, est destinée au dépôt et à la diffusion de documents scientifiques de niveau recherche, publiés ou non, émanant des établissements d'enseignement et de recherche français ou étrangers, des laboratoires publics ou privés. 


\section{Automotive Supplier Parks: An Imperative for Build-to-order?}

Published: Journal of Purchasing and Supply Management V.12, Iss.2, pp.91-104

\section{Mickey Howard +}

Operations \& Supply Group, School of Management, University of Bath, Bath, BA2 7AY, United Kingdom. mnsmbh@management.bath.ac.uk

Tel. $+44(0) 1225383682$

Fax. +44 (0)1225383902

\section{Joe Miemczyk}

Innovative Manufacturing Research Centre, School of Management, University of Bath. Bath, BA2 7AY, United Kingdom. mnsjrm@management.bath.ac.uk

Tel.+44 (0)1225383873

Fax. +44 (0)1225 826135

\section{Andrew Graves}

Innovative Manufacturing Research Centre, School of Management, University of Bath. Bath, BA2 7AY, United Kingdom. mnsapg@management.bath.ac.uk Tel.+44 (0)1225 826641

Fax. $+44(0) 1225826135$

(Version: Revision 2)

Original submission: January 2005

First revision submitted: October 2005

Second revision submitted: April 2006

$\dagger$ Correspondence author 


\title{
Automotive Supplier Parks: An Imperative for Build-to-order?
}

\begin{abstract}
Build-to-order (BTO) has been hailed as a production strategy that fits the demands of the $21^{\text {st }}$ century where a considerable challenge for the industry is how to achieve flexibility from extended supply chains that span the globe and retain elements of make-to-forecast. A study of 8 European manufacturers examines whether supplier parks are an imperative for BTO using a conceptual framework developed from the literature. The findings question the idea that simply locating suppliers in close proximity to OEM assembly plants reduces delivery lead time and inventory. Hence, not all types of supplier parks are an imperative for BTO, where the cases reveal a wide variety of types ranging in scale and proximity. The originality of the paper is a unique study which redefines both automotive supplier park terminology and the relationships with BTO. It questions received wisdom and offers practical measures for industry.
\end{abstract}

Keywords: Supplier parks, build-to-order, proximity, flexibility. 


\section{Automotive Supplier Parks: An Imperative for Build-to-Order?}

\section{Introduction}

Build-to-order (BTO) has been hailed as a production strategy that fits the demands of the $21^{\text {st }}$ century, fulfilling customer orders in short lead times through responsive manufacturing and information exchange (Gunasekaran, 2005; Holweg \& Miemczyk, 2002; Holweg \& Pil, 2004; Howard, Vidgen, \& Powell, 2003). Yet a considerable challenge is how to achieve flexibility from extended supply chains that retain elements of the destructive cycle of make-to-forecast (Holweg \& Pil, 2001). Today automotive supply chains hold weeks of component stocks, driven

by a combination of vehicle manufacturer forecasts and supplier concerns over 'stock-out' arising from quality or delivery issues. Globalisation of the industry has meant that low value vehicle parts are now shipped from all corners of the world. For instance, to complete an engine assembly in the United Kingdom, the oil pump takes 8 weeks to arrive from South Korea, represents 26 days worth of inventory, and travels over 8000 nautical miles. One way to achieve the increased level of flexibility demanded by BTO in recent years is through clusters of suppliers located in close proximity to production; we define this as a supplier park.

Supplier parks are emerging as increasingly common in automotive and other industries, yet supplier parks and the implications for responsiveness are loosely defined in operations literature (Chew, 2003; Cullen, 2002). The case of Dell demonstrates the implications of BTO on the operations of a plant and the effect on suppliers. The Dell plant in Limerick, Ireland, is a factory driven purely by customer orders. With no Dell-owned warehouses serving the factory, the suppliers have to respond to requests within two hours. Hence all suppliers have local hubs and hold around two weeks stock to satisfy demand. Orders are received every 15 minutes to a factory that holds only 4 hours stock and delivers an average fulfilment promise of between 5 to 7 
days (Davis, 2005). As an example of customer responsiveness, Zara also stands out as an exemplary case, demonstrating in 2003 that it could design and deliver garments to its 600 stores in over 30 countries in only 15 days. This is made possible through a closely coupled design and order administration, and tightly controlled production network of 22 factories in Spain.

Furthermore, $70 \%$ of Zara's suppliers (out of 400) are based in Europe allowing a quick response to orders from the Zara factories (Ferdows, Lewis, \& Machuca, 2003).

Current descriptions of supplier parks in the automotive industry include 'decentralised production in local assembly units ... are located close to the car assembly plant' (Millington, Millington, \& Cowburn, 1998 p.180), and 'a confined area in proximity to the assembly plant' (Larsson, 2002 p.769). Given that supplier parks have been used for over a decade - for instance SEAT in Barcelona - it is surprising that the links with BTO have not been explored sooner. Hence, the aim of this research is to identify the role of supplier parks in BTO, and ask can they be considered an imperative for build-to-order? Eight cases of supplier parks are examined across Europe, where the phenomenon under investigation is build-to-order and the unit of analysis is the supplier park. The paper develops a conceptual framework derived from the literature with which to explain the data and provide a clearer understanding of the drivers, moderating factors, and outcomes. The current gap in knowledge over how supplier parks may facilitate BTO justifies the use of an exploratory multiple case study. In this context case studies are considered one of the most powerful methods in operations management particularly in the development of theory (Stuart, McCutcheon, Handfield, McLachlin, \& Samson, 2002; Voss, Tsikriktsis, \& Frohlich, 2002).

\section{Literature Review}

This section describes the objectives and requirements of build-to-order and the supporting role of supplier parks in the automotive industry. The literature review is structured by examining the 
drivers and factors of supplier parks to support build-to-order (Figure 1). Several questions emerge from the literature, which underpin the conceptual framework used to structure the enquiry and focus our analysis.

\section{Take in Figure 1}

\subsection{Build-to-order objectives}

Build-to-order requires different performance objectives from traditional mass production approaches such as make-to-stock. Hence, before devising a supply chain, Fisher (1997) recommends considering factors such as the predictability of demand for the product and the need for physical efficiency and market responsiveness. Fisher argues that it is the drive for efficiency in the process of supplying innovative high variety products in industries such as automobiles, personal computers, and other consumer goods that accounts for so many broken or unresponsive supply chains. In their seminal paper, Holweg and Pil (2001) use the ideas of Slack (1991) and Upton (1994) to develop core objectives for BTO: processes, product, and volume flexibility. Flexibility is defined by Slack (1991 p77) as the '...ability to change, to do something different' whose framework includes aspects of flexibility not only across the total operation or system, but also the supply network. First, suppliers need to be integrated so that they can see orders based on real demand from customers, allowing process flexibility in the supply chain. Second, customisation needs to be brought closer to the customer instead of relying on finished goods, hence enabling product flexibility (Ward \& Duray, 2000). The third objective - volume flexibility - requires negotiation with workers and suppliers to reduce the dependence on full capacity utilisation (Slack, 1991).

One of the main requirements from a supply chain perspective is to closely tie supplier production schedules into customer production schedules (Holweg et al., 2001). Geographic 
distance can be a major constraint to this level of integration between suppliers and customers for the following reason. The daily assembly schedule and vehicle assembly sequence is of little use where suppliers are located hundreds or thousands of miles away with commensurately long delivery lead times. Hence suppliers and customers hold stocks to cope with the issues of lead time and schedule variability. Strategies are needed to control the cost of flexibility for BTO where suppliers are continually under pressure from the original equipment manufacturer (OEM) to reduce the time needed to deal with variations between planned production and actual orders. One such strategy is the development of the supplier park.

\subsection{What are supplier parks?}

The co-location of supplier facilities has been described as relating to the choice of individual suppliers to set up a dedicated facility close to a customer (Millington et al., 1998). Previous authors have used terms such as 'local assembly units' or 'local dedicated units' which refer to geographically close individual supplier ties (Larsson, 2002; Millington et al., 1998). The broader concentration of production sites is commonly known as an 'industry cluster' and may be thought of as including supplier parks within that definition (Saxenian, 1994). We develop our own definition of supplier parks because to date they have been only described superficially, in the broadest sense of the term. Thus a supplier park is defined here as:

'A concentration of dedicated production, assembly, sequencing or warehousing facilities run by suppliers or a third party in close proximity - i.e., within $3 \mathrm{~km}$ - to the OEM plant.'

The number of automotive supplier parks have grown over the past decade especially in Europe and currently total 23 sites. Most OEMs have implemented some kind of supplier park including Ford, GM, Fiat, Peugeot, Renault, BMW and Volkswagen (Chew, 2003). The supplier parks used in this study are listed in Appendix A. Typical activities carried out in automotive supplier parks include warehouse and inventory management, sequencing, manual assembly and late 
configuration, and range in size consisting of between 7 and 24 suppliers (Cullen, 2002; Kochan, 2002).

The motivating principles - or drivers - for developing supplier parks appear to vary across the descriptions of supplier parks. That supplier parks themselves vary widely (i.e., size, location, activity), suggests there is no simple relationship between drivers and characteristics of supplier parks. This paper draws from contingency theory to develop internal and external moderating factors (Kast \& Rosenzweig, 1981) which may intervene before supplier parks enable BTO. Drivers and factors are discussed in the next section.

\subsection{Drivers towards supplier parks}

One of the key trends in the automotive sector is the increase in variant numbers of individual models of car (Holweg \& Greenwood, 2001). This trend has led to an increase in the part numbers required by assembly plants and thus had an impact on the inventory policies of vehicle manufacturers (VMs) and the general need to maintain mix flexibility to remain competitive (Berry \& Cooper, 1999). In this case assembly plants either hold a greater amount of inventory to ensure of supply of the correct parts or install more responsive supply chain processes such as sequenced in-line supply (SILS). Where SILS has been implemented the time between a car starting final assembly and the fit point of the particular part (such as a seat) is given to a supplier to deliver the part exactly as specified (Doran, 2001). Where this short order cycle time is only a matter of minutes, the supplier is often located close to the OEM plant (Larsson, 2002).

Another trend related to increasing product variety in the automotive industry is the move towards simplifying production by introducing modules (Fredriksson, 2002; Hsuan, 1999; Sako \& Murray, 1999). Arguments for modular supply include cost reduction through lower supplier wages and overheads, and inventory reduction, increased space and simpler transactions (Baldwin \& Clark, 1997; Doran, 2003; Von Corswant \& Fredriksson, 2002). Firms can mitigate the negative impact of product variety on operational performance by using modularity in the design 
of product family architectures (Salvador, Forza, \& Rungtusanatham, 2002). Taking modular supply to the extreme leads to the idea of 'modular consortia' where each module supplier locates next to the OEM plant, and has responsibility for all suppliers into the module, investing in the facility with the OEM and even assembling the module directly into the vehicle in some places (Collins, Bechler, \& Pires, 1997). In theory, the practice of configuring complex product architecture through modular design with standard interfaces (Sanchez \& Mahoney, 1996), enables greater flexibility when considering supply chain strategies such as outsourcing (Hsuan, 1999). Yet current practice shows that supplier parks are also represented by suppliers of commodity components (e.g. nuts and bolts), parts which are bulky, and high variety parts which can be late-configured just before delivery to the vehicle assembly line.

Volume flexibility is seen as a further key to obtaining competitive advantage and there are a number methods by which manufacturing firms can achieve this (Jack \& Raturi, 2002). The decision to co-locate a supplier facility near the OEM assembly plant can also be driven by a need for volume flexibility, for example where capacity is taken by an additional assembly line. The cost to hold this inventory may be shifted to the supplier instead of making use of an OEM controlled warehouse.

A significant driver for setting up a co-located supplier facility is the opportunity for funding development of local production sites. Regional and local development agencies often have funds to establish production sites especially in areas identified as economically disadvantaged, for example where European structural funds are made available (Larsson, 2002). Regional development agencies may then approach large production facilities to offer them a subsidised infrastructure for further development of production facilities to encourage economic growth.

\subsection{Moderating factors affecting supplier parks}


While the previous section describes drivers, this section identifies factors that moderate how supplier parks support the objectives of build-to-order.

\section{Start up costs}

The common objective for government funding for supplier parks tends to centre round assisting the vehicle manufacturer to remain competitive (Larsson, 2002). If the investment cost for increasing flexibility is high then assistance from local authorities is likely to be sought. However, the extent to which these agencies will fund the development may affect the ability to achieve the proposed objectives, and more specifically enable build-to-order. If the funding covers the development of all production facilities then the cost of initial start-up may be significantly lower than if only basic infrastructure such as road links are included. Therefore start-up costs have a significant impact on the overall cost of increasing flexibility.

\section{Choice of supplier and asset specificity}

The choice of supplier brought onto a supplier park will depend on the type of component or module being supplied. Co-location is likely where the part is specific to a particular vehicle, such as seats, cockpits, or external structures such as bumpers. This is especially the case where there are a number of variants of the part per model. Bulky parts such as front and rear-end modules that are costly to ship are also likely to be brought within close proximity to the final assembly line. Typically these product sub-systems (or modules) have been integrated into manufacturers' operations, but the trend in recent years has been to outsource more of these major 'chunks' of the product architecture, thus increasing distance between assembly operations (Sako \& Warburton, 1999b). Such transactions can be thought of as having 'high asset specificity' - an attribute with a number of associated problems.

Transaction cost economics argues that assets specific to a transaction are more likely to be internalised than non-transaction specific assets (Williamson, 1979). Thus if a supplier delivers 
parts which are specific to one vehicle then the OEM is more likely to seek hierarchical control to reduce opportunism. Asset specificity is a key concept to understanding the benefit of specialized supplier networks according to Dyer (1996). For example, site specificity has been described as where 'successive production stages are located in close proximity to one another to improve coordination and economize on inventory and transportation costs' (Dyer, 1996 p.273).

A particular problem that can occur is opportunistic re-contracting, where either the buyer or supplier can act opportunistically when contracts are renewed (by increasing prices or decreasing service levels, for example). Klein et al. (1986) describe the dealings that culminated in a vertical merger in the 1920s between General Motors (GM) and Fisher Body, a leading supplier of the new style of closed auto bodies. An exclusive dealing arrangement significantly reduced the possibility of GM acting opportunistically by demanding a lower price for the bodies after Fischer made the specific investment in production capacity. Unfortunately, these pricing provisions did not work out in practice. The shift in demand from open towards closed-style bodies meant GM was unhappy with the price it was being charged by its now very important supplier. In addition, Fisher refuse to locate their body plants adjacent to GM's assembly plants, a move GM claimed was necessary for production efficiency, but which required a large and very specific investment on the part of Fisher. Finding the contractual relationship intolerable, GM began negotiations for purchasing the stock of Fisher Body, culminating in a final merger agreement in 1926.

The degree to which post-contractual opportunistic behaviour occurs is dependent on how specific the assets are to the transaction, and therefore how difficult it is to write contracts accounting for all contingencies. If supplier facilities at supplier parks have highly specific assets (i.e. physical, human, and site-related) then the risks of opportunistic re-contracting is higher (Millington et al., 1998). Specific assets can also lead to strategic inflexibility as the OEM is dependent on the co-located supplier. In terms of supplier parks this issue was summarised by one automotive supplier as 'while the set-up fosters a long-term partnership, it reduces flexibility in 
quality or cost disputes' (Cullen, 2002). Both these issues lead to a lack of supply chain flexibility, arguably an undesirable attribute for build to order.

\section{Institutional norms}

Outsourcing capacity also influences the development of a supplier park. Capacity at the OEM plant, such as assembly of modules, can be outsourced to a supplier to increase flexibility required for BTO (Sako et al., 1999b). A considerable barrier to the successful achievement of this are the institutional norms which develop in firms in order to build legitimacy (DiMaggio \& Powell, 1991). One type of institutional norm that has a particular influence over manufacturing firms is the presence of strong unionization - established to protect the interests of the workforce. OEM trade union representatives may not agree that efficiency benefits will be gained from outsourcing production operations and that the interests of the work force will be downgraded, hence the union is likely to resist such a move. Such resistance to outsourcing operations has been well documented, for example at the General Motors Lansing assembly plant over the outsourcing of module assembly (Marinin \& Davis, 2002). Lean strategies are neither wholly supported nor resisted by unions, and questions still arise over the effect of these institutional norms (Shah \& Ward, 2003).

\section{JIT Capability}

Just-in-time (JIT) refers to the movement of material to the right place at the right time. Elements essential to its success concern the capability of suppliers to participate through information technology thereby enabling frequent communication (Wafa, Yasin, \& Swinehart, 1996). JIT supply into vehicle manufacturers is expected to increase in the future with more suppliers having to cope with its associated demands (Von Corswant et al., 2002). Schonberger and Gilbert (1983) propose that the success of JIT practised by firms implementing lean principles is associated with 
geographically proximate suppliers. However, research has also shown that this is not always the case (Wafa et al., 1996). Specifically, information and communication technologies are able to mitigate the effects of distance on successful JIT defined as reductions in inventory, component rejects, and delivery lead time. Thus, if JIT capability is necessary for BTO in the automotive sector, the co-location of suppliers may be less critical. Yet it has also been shown that geographical proximity of suppliers affects the trade-off between product variety and operational performance when mitigated by modularity (Salvador et al., 2002). These differing views question the assumption for close proximity in JIT strategies as an enabler for BTO.

An alternative perspective argues that proximity provides additional benefits to JIT capability such as the development of knowledge-sharing (Dyer \& Singh, 1998). Work relating to industry clusters indicates that the sharing of knowledge within these industrial groupings provides for the development of specific capabilities (Saxenian, 1994). It follows therefore that the capability for JIT could be enhanced by close proximity of supplier to supplier, and supplier to OEM, whereby tacit knowledge is transferred between firms within the industrial cluster, or in this case the supplier park.

\section{Supply chain disturbance}

There are many causes of supply chain disturbance that in turn affect the reliability of delivery.

One of the causes of supply chain disturbance is where distant suppliers are more likely to experience disruptions in delivery, for instance problems experienced as a result of the transport infrastructure or from extreme weather conditions (Svensson, 2000). This has been described as one of the primary factors affecting the adoption of supplier parks (Cullen, 2002). Yet disturbances are not only limited to transport problems and can include events at supplier production sites such as strikes and machine breakdowns (Svensson, 2000). It is unclear from existing research whether bringing suppliers close to their customer manufacturing sites does indeed reduce these types of disturbances overall. 
To understand the role of supplier parks in BTO strategy we develop a conceptual framework to structure our inquiry, based on the drivers, factors, and outcomes. Figure 1 shows that the 'outcome' of developing supplier parks for BTO can be thought of as dependent upon drivers and moderated by factors. We argue that the drivers centre on the primary requirements of build-toorder i.e. product mix and volume flexibility, with the addition of funding incentives that affect the decision to set up a supplier park. Factors moderate the relationship between drivers and outcomes. This approach uses contingency theory that is based on the alignment of endogenous and exogenous variables (Kast et al., 1981). Figure 1 provides the focus of our enquiry headed by the question - how can supplier parks be considered an imperative of build to order? Using our framework as an exploratory tool this can be divided thus:

'What relationship of drivers and factors produce particular outcomes?'

'Can supplier parks be classified according to their support for build-to-order?'

\section{Take in Figure One}

\section{Method}

This study adopts an exploratory case study (Marshall \& Rossman, 1989; Yin, 1994) to investigate whether supplier parks are an imperative to build-to-order in the automotive industry. While there are already several studies that describe the effects of BTO in the automotive sector (Gunasekaran, 2005; Holweg et al., 2004), this research aims to explore how the phenomenon interacts with the supply chain using supplier parks as the unit of analysis. It adopts a multiple case approach which uses the rationale of theoretical replication, not statistical sampling logic, where each case is selected so that it 'either predicts similar results, or produces contrasting results for predictable reasons' Yin (1994, p46 ibid). While ideally all 23 supplier parks in Europe would be investigated, limited resources and our exploratory approach meant 8 supplier parks were chosen as representing one or more factors from the conceptual framework (see 
Appendix B for the case selection criteria) i.e. drivers and general characteristics of the customer (volume or premium manufacturers), that affect support for BTO (Table 1).

\section{Take in Table 1}

The study divides the cases into supplier parks which enable BTO, those with potential, and those which do not. It concludes with a matrix showing the relative position of all 8 cases in terms of their capability to provide support for BTO. The number of cases adopted here is consistent with good practice in case research where 'the ability to conduct six to ten case studies' is analogous to conducting a similar number of experiments on related topics.

Case research is considered one of the powerful research methods in management studies, particularly in the development of new theory (Eisenhardt, 1989; Voss et al., 2002). Yet practical problems can occur when attempting to systematically combine theoretical framework, empirical fieldwork and case analysis (Dubois \& Gadde, 2002). This study adopts a conceptual framework based on the synthesis and interpretation of existing literature (see Figure 1). As the framework is developmental and broad, we argue the approach here is positioned as 'exploratory' where the aim is to develop more precise hypotheses on the relations between the different variables. Eisenhardt (1989) and Checkland (1991) underline the importance of the prior development of a framework to guide data collection and analysis. This provides a means of coping with the 'flux of events and ideas in a real situation' and requires the explicit declaration of an intellectual framework of ideas and research themes (Checkland 1991, p.400). While the framework may require rethinking as the researcher tries to make sense of the accumulating experience, it forms a secure point of reference during and after the field study, and as an instrument with which to compare with the literature.

The idea to investigate supplier parks emerged from an earlier research programme, '3Daycar', which studied the implications of introducing customer order fulfilment in the United Kingdom. 
3Daycar shows that on average 40 days are needed in the UK to build and deliver a new vehicle, from order entry at the dealership to final customer delivery. Yet only one day is actually spent building the vehicle (Holweg et al., 2001). During a visit to the DaimlerChrysler Smart factory in May 2000, the response by personnel on the site suggested the proximity of suppliers in relation to vehicle manufacture is a significant factor that may improve BTO capability. This visit piloted the research and stimulated the development of the conceptual framework. Construct validity was addressed by discussing draft interview and case reports with research participants and adjusting these on the basis of their comments (Yin 1994). A case protocol (Appendix B) strengthened reliability during case selection, interview questioning and general procedure during site visits and interviews. 30 semi-structured interviews were conducted over an 18 month period involving 17 site visits across Europe. Draft interviews and case reports were discussed with research participants and adjusted on the basis of their comments. The method of data analysis ensured internal validity through the process of codifying responses from each case and presenting them in tabular form for cross-case comparison and pattern-matching (Miles \& Huberman, 1994). The use of replication logic as part of the research design reinforced external validity, where patterns began to emerge across the cases as similarities and differences in the drivers, factors and outcome of supplier park support for BTO. Finally, the research was disseminated by presenting the results at academic conferences as well as industry seminars organized by the Society of Motor Manufacturers \& Traders (SMMT) and the International Motor Vehicle Programme (IMVP) (Miemczyk, Howard, \& Graves, 2004).

\section{Findings}

This section briefly describes the findings from the eight sites across Europe. The findings are summarised in Table 2 by the number of suppliers located on the supplier park, number of vehicle 
models it serves, the distance in kilometres from the OEM assembly plant, annual OEM production volume, supplier park age, and country of location.

\section{Take in Table 2}

\subsection{Supplier park case descriptions}

Seat, Abrera

The supplier park at Abrera, near Barcelona in Spain, is located 2.5 kilometres from the Seat assembly plant. The park was established in 1992 when the main Seat assembly plant was moved from the suburbs of Barcelona to an industrial district 50 kilometres away. This move coincided with the development of a supplier park. The site was financed by an investment company that rents the site to the users of the park (the suppliers and logistics providers). The area of the site was increased by $30 \%$ in 1998 to cope with an expansion in capacity at the vehicle assembly plant. The site now operates with 32 suppliers carrying out a number of operations including inventory management, consolidation, late-configuration and assembly tasks, with all components being delivered in sequence to the plant by a third party logistics provider. The transportation is by truck with a 10 minute journey time. Around 946 journeys are made per day delivering 63 component sets to three vehicle assembly lines.

\section{Ford, Bridgend}

The site at Bridgend, Wales was chosen specifically because it only assembles engines for Ford Motor Company and, more recent members of the Premier Automotive Group (PAG) such as Volvo and Land Rover. Many other Ford sites have associated supplier parks e.g. Valencia Spain, Cologne Germany, and Bridgend plant managers view this as an important part of their own strategy to cope with increasing pressures from Ford and other PAG customers. The site faces many of the issues that traditional vehicle assembly plant supplier parks face such as increasing 
volumes and variety, the opportunity for government funding, as well as critical supplier issues affecting competitiveness such as the need for global sourcing. While construction of the park infrastructure has been completed and the plant is currently receiving deliveries from one supplier, Bridgend is still negotiating with other suppliers involved with JIT delivery to ascertain mutually beneficial conditions for their re-location.

\section{GM, Ellesmere Port}

The Ellesmere Port supplier park is another recent introduction following a re-organisation of the sequencing operation in 2001. The Ellesmere Port plant assembles two models, the Astra and Vectra for Vauxhall (UK) and Opel (Europe) brands. The introduction of a new model led to a reclassification of this facility to 'flex-plant' in order to cope with demand variability in the European market, hence the re-organisation of inbound logistics and supply. Originally two suppliers were located close to the plant, followed by the introduction of a new consolidation and sequencing centre. The park includes a whole range of activities from light assembly and late configuration, to sequencing and warehousing. There are now four suppliers onsite, including a third party logistics provider (3PL). One supplier and the 3PL handle the sequencing for the other suppliers as well as sequencing inbound deliveries from suppliers located across the UK and Europe.

Volvo, Gent

Established in 1999 the supplier park supporting the Gent assembly plant supplies components and modules in sequence to Volvo assembly plant. The suppliers are dispersed over an area between 1.5 and $3 \mathrm{~km}$ from the plant. The OEM plant assembles 2 different models with an annual target volume of 160,000 cars. There are fifteen suppliers at the park supplying modules ranging from headliners, seats, tailgates and bumpers. The site was developed by a property services company with $10 \%$ of the investment costs met by Volvo and suppliers. Trucks are used to 
transport the goods to the assembly plant with around 175 deliveries per day. The supply of goods is organised by Volvo and line-side inventory is also financed by the OEM.

\section{Jaguar, Halewood}

The development of the supplier park at Halewood coincided with the ending of Ford Escort production and the beginning of Jaguar X-Type production in 1999. The site is not dedicated to automotive suppliers, as a pharmaceutical firm also occupies the facility. The transition to Jaguar

production led to a major reduction in capacity needed at the plant, leading to a re-organisation of the production layout and a reduction in the labour force. The park itself employs 850 personnel through the automotive suppliers. The area is designated 'objective one' which means that it qualified for European structural funding. This was used to pay for much of the development of the supplier park.

\section{Audi, Ingolstadt}

The Audi supplier park at Ingolstadt is an established site with eleven suppliers on site and a range of activities being carried out at the site. The site was developed to cope with an increase in both vehicle production volume and product variants, with Audi/VW adopting a module and platform strategy to decrease overall costs and increase flexibility. The site is $100 \%$ funded by the local government who lease it to suppliers and Audi. The site also houses general consolidation activities from a range of automotive suppliers. Ingolstadt is limited in its capacity for final assembly of vehicles hence some painted bodies are shipped to other locations in Germany and Hungary for this final stage of production. The supplier park is intended to assist this operation in addition to sequencing parts for final assembly on site.

\section{MG Rover, Longbridge}

The development of this supplier park was initiated by the re-structuring of manufacturing at Longbridge. When BMW relinquished control of Rover Group Birmingham in 2001, its new 
flagship model the 'Rover 75' had to be relocated from its Oxford production site, to Longbridge. The previous production location already had a number of co-located suppliers assisting with insequence delivery, thus the intention was to replicate this at the new site. Longbridge was also undergoing change and spare capacity led to the availability of space for suppliers within the assembly site itself. However, only three suppliers followed the Rover 75 to its new location. These firms supply the ' 75 ' assembly line, with three other vehicle models being served by more distant suppliers. The original production ethos of the 75 was to build to order, hence the use of a supplier park and sequencing centre was central to this strategy.

\section{Volvo, Torslanda}

Established in 1999, the supplier park at Arendal in Sweden supplies components and modules in sequence to the Torslanda Volvo assembly plant $3 \mathrm{~km}$ away. The OEM plant assembles 4 different models with an annual target volume of 170,000 cars. There are 15 suppliers at the park supplying modules ranging from headliners, seats, tailgates and bumpers. The site was developed by a property services company with $10 \%$ of the investment costs met by Volvo and suppliers. Trucks are used to transport the goods to the assembly plant with around 192 deliveries per day. The supply of goods is organised by Volvo with line-side inventory also financed by the OEM. The sequencing system is run by the suppliers on the park and provides signals every minute for a four hour delivery horizon.

\section{Analysis and discussion}

The data from the cases require codification or a common classification to enable cross-case comparison. The conceptual framework guides the classification of case data into drivers, factors and outcomes. Drivers are classified in terms of the need for product mix flexibility, the need for volume flexibility, and the availability of public funding. Factors are variables that moderate the 
relationship between drivers and outcomes. The combination of factors and their specific attributes vary case by case. The attributes of start-up costs are high or low (where high relates to significant new developments in infrastructure and low represents re-use of existing facilities and significant external funding) ${ }^{*}$. The attributes of asset specificity are primarily high or low, but include site, plant, and personnel-related assets, and the risk of strategic inflexibility (again high and low referring to the two extremes of specific modules such as cockpits or unspecific products e.g. nuts and bolts). Two elements of institutional norms are encountered here and focus on union resistance and mimetic behaviour that follows perceived industry best practice. The attributes of JIT capability centre on who holds the requisite skills and competencies to co-ordinate sequenced in-line supply. Supply chain disturbance is perceived as either present or absent in terms of the impact on component supply. This research finds cases of transportation disturbance and attempts to mitigate this through late configuration. Some additional factors are also presented in Table 3 that fall outside of the original classification e.g. change in corporate strategy.

\section{Take in Table 3}

The outcomes from the research emerge in the form of different supplier park types in terms of scale, proximity, and capability to enable supply chain flexibility e.g. 'large-scale distant', 'small scale onsite' (Table 3). The cross-case analysis reveals that there are differences in the characteristics of supplier parks in this study. From a physical perspective the supplier parks vary in size and location in relation to the vehicle assembly plant they serve. The parks also appear to differ with respect to how they enable build-to-order, and how the moderating factors affect the drivers for the development of supplier parks. The analysis now examines supplier parks that enable BTO, supplier parks with the potential to enable BTO, and supplier parks that do neither.

\footnotetext{
* Using high/low measure was necessary due to the lack of available objective measures to distinguish between the factors.
} 


\subsection{Supplier Parks that enable BTO}

The Volvo, Audi and Seat supplier parks are all large in scale with a significant amount of supplied value routed through the parks ( $80 \%$ in the case of Volvo). They are also distant from the assembly plant providing for some capacity flexibility if expansion is required, except in one case, Audi, which has limits to capacity variation due to union resistance. Each park had low start up costs as a result of external funding. Asset specificity is viewed as high, but in the case of Volvo, obligational contractual relationships allows the risk of opportunism and strategic inflexibility to be reduced supporting Dyer's (1996) statement that the gains of specialization can outweigh the costs. The drivers for these parks come from the need to provide volume and mix flexibility in the supply chain, to reflect flexibility in the assembly plant, of which Volvo are particularly known for their build-to-order strategy. Capability in JIT operations in these cases is held by the OEM (with a strong control and coordination role). Yet this is not the case at Seat, where much of the capability is held by the third party logistics provider.

Overall, these parks enable BTO at the assembly plant because of the need for volume and mix flexibility. There is the additional benefit of low start up costs, and the potential for strategic inflexibility is moderated by favourable supplier relations. This results in large-scale supplier park operations with high levels of outsourced in-sequence component supply.

\subsection{Supplier parks with the potential to enable BTO}

Supplier parks with the potential to enable BTO include MG Rover Longbridge and GM Ellesmere Port. These are small-scale adjacent or onsite parks of insufficient size to provide significant support build-to-order strategy. Moreover, the reasoning for their introduction is driven by either the need to use spare capacity (in the case of MG Rover) or the need to provide spare capacity for a sister facility in continental Europe (in the case of GM). The start up costs were not financed by an external body, which in turn affects the economics of locating suppliers 
close to the plant. However, other moderating factors also provide reasons why these sites might provide the potential for supporting BTO. The capability to provide in-sequence supply is being developed at both sites, thus supporting a process to provide product mix flexibility, especially as late configuration is introduced at both sites. Furthermore, the reduction of supply chain disturbance as a result of unreliable transportation provides conditions that are supportive of build-to-order.

The principles behind these small-scale cases in theory support BTO at the vehicle assembly plants. However, despite their potential they are inhibited by the lack of scale of the operations, in one case this was the result of falling vehicle sales, and in the other due to sharing production with a sister site.

\subsection{Supplier parks that do not enable BTO}

The evidence from the last two cases, Ford and Jaguar, suggests these supplier parks do not enable BTO and have limited potential to do so in the future. In both cases the strongest driver appears to be the availability of external funding for the required supplier park infrastructure. For Jaguar, the original intention to build a supplier park was to provide volume flexibility, but a change in manufacturing strategy at European level has removed this requirement. Yet the park was established, suppliers co-located, and in-sequence supply initiated. The long call-off lead times of 12 hours removes the urgency of in-sequence supply, as this period of notice does not require close supplier location. In the case of Ford, while park infrastructure has materialised, only one supplier has located to Bridgend and a viable business case has still to be made to other partners. Evidence shows that this site demonstrated mimetic behaviour in that other Ford plants had already implemented supplier parks and reported performance improvements. While the plant was driven by a need for product mix flexibility (the number of engine variants produced had rapidly increased), the benefits of co-located suppliers to improve JIT capability and BTO were unclear. The types of suppliers would also produce high opportunism and strategic inflexibility 
issues especially where primary manufacturing such as forging, casting, or machining were needed, as significant investment in supplier plant and personnel would be required.

Hence, for these last two cases the drivers for BTO were largely absent. In the case of Jaguar the supplier park was not implemented to provide build-to-order advantages, and space on the park was utilised by non-automotive companies removing potential volume flexibility advantage. The Ford engine supplier park has only part materialised, despite external funding. The decision process for Ford may need re-aligning towards the benefits for build-to-order and an examination of whether engines could and should be produced just-in-time.

\subsection{Supplier parks: an imperative for build to order?}

Three supplier park types have emerged from the cross-case analysis supported by Table 3. First are supplier parks that enable BTO because they are large-scale, catering for volume and product mix flexibility. Start-up costs are often minimised through public and private funding. Second are supplier parks that in theory support BTO, but are small-scale, where drivers for either volume or product mix are lacking. Third are also small or underdeveloped supplier parks that do not support BTO because of overall weak drivers for flexibility and recent changes in manufacturing strategy. This paper identifies a pattern between supplier park types, proximity, strategic BTO flexibility, and scale. These relationships are plotted in Figure 2.

\section{Take in Figure 2}

Figure 2 shows a relationship between supplier park proximity and type. The analysis demonstrates that large-scale parks that enable BTO are associated with being 'distant' (more than $1 \mathrm{~km}$ ) from the OEM assembly plant. Supplier parks that are geographically distant offer greater opportunity for expansion than onsite or adjacent parks, and hence are more flexible. These parks are driven by both volume and product mix flexibility, and combine several moderating factors which enable BTO. This is shown in Figure 2 as strategic BTO flexibility. The 
parks which do not enable BTO or only possess potential to do so are adjacent or onsite and are limited by the constraints of surrounding OEM infrastructure. According to this research adjacent and onsite parks are driven - at most - by either volume or product mix. Several moderating factors also need be considered in cases where the capability for BTO was less evident. For instance, changes in corporate strategy, union resistance to changes in working practice, and the difficulties of persuading suppliers to invest in an appropriate level of asset specificity.

Returning to the research question, this paper indicates that only certain types of supplier parks are an imperative for build-to-order, described here as distant from the OEM assembly plant, providing strategic BTO flexibility, and possessing sufficient scale. The combination of factors and drivers that lead to this type are volume flexibility, product mix flexibility, low start-up costs, and managed asset specificity.

\section{Conclusions}

This study finds there are a number of different types of supplier park, yet only some of these have the characteristics to enable BTO. These are large-scale sites, 1 kilometre or more distant from the OEM assembly plant, and providing both volume and product mix flexibility. The supplier parks that do not enable BTO are small-scale, and provide volume and product mix flexibility only to a limited degree. These parks are characterised as onsite or adjacent to the OEM assembly plant.

In terms of research limitations, this is a European study where concepts such as the availability of public funding may be idiosyncratic to this region. While 8 cases out of a European total of 23 is a good representation, a wider study across the total population including the US, South America, and Japan might include additional variables. Case study methods are appropriate for 
explanatory research, yet further theory testing could be enhanced through cluster analysis techniques covering supplier parks world-wide.

It is important to note that change is the 'normal' state for the automotive industry and this could have ramifications on the factors that influence decisions on future supplier park development. The increasing trend in modularisation and supplier alliances (e.g. Hella, Behr, and Plastic Omnium developing complete front-end modules) suggests an increased position of power for first tier suppliers. Their desire for scale effects could further restrict co-location opportunities. This could also lessen the effect of specific technologies (assets), as more components of modules are shared over more end products. A further interesting development is the desire for some vehicle manufacturers to remove nearly all short term variability in their supplier schedules (through better schedule reliability). This development could potentially reverse the trend in colocating suppliers altogether, where suppliers no longer need to respond to short term variability in material volume and mix requirements.

This study has significant implications for theory. Contrary to received wisdom that supplier parks have developed because of the disruption caused by extended supply chains (i.e. Korean fuel pumps shipped to the UK) we find they are adopted for a variety of reasons. This includes the availability of public funding, corporate re-structuring, and the result of changes in strategy in addition to the more apparent need for volume and product mix flexibility. Supplier parks become an imperative for build-to-order in cases of increasing demand to deliver high product variety, the ability to cope with fluctuation in volume, and the capability to respond in short order lead times. This research supports Dyer's (1996) view that competitive advantage in the form of build-toorder is contingent on type of activity and degree of interdependence between OEMs and suppliers to achieve flexibility. A surprise finding is that supplier parks in close proximity to the OEM do not necessarily foster closer working relationships and knowledge sharing for BTO. 
Hence, more distant supplier parks are better placed to enable build-to-order than onsite or adjacent parks. This questions the 'closer is better' hypothesis of Saxenian (1994).

Returning to the conceptual model raises the issue of how well the model reflected the divergence in supplier park approaches. The model's use of drivers appears to adequately predict supplier park development although the mix of each set of drivers is variable across each case.

Furthermore, those parks which appear to support build-to-order do so as a result of a combination of factors related to improving JIT capability, reducing supply chain disturbances and require integration due to the level of specific assets (e.g. supplier's products and processes that can not easily be switched to other OEMs). The start up costs and institutional norms appear to moderate whether supplier parks can actually be implemented, for example where costs are supported by an external agency and unionisation does not limit managerial choices on activities that take place in supplier parks. Company strategic direction, should also be included as a further moderating factor (either positive or negative) in the model to account for issues that emerged from the cases. Hence, factors can be categorised into 'barriers to implementation' and 'enablers to build to order'. Further work should test these categories of factors across different cultural contexts to assess generalisability. Build-to-order remains an under-defined construct, and while it was not the focus of this work to develop this, continued research should focus on defining build-to-order and its role in sustaining competitive advantage. More generally, research should attempt to empirically link the benefits of proximity (in terms of information and knowledge sharing, reduction in supply disturbance etc) with the overall performance of the supply chain as well as the performance of individual firms in that chain. While there are clear potential benefits for OEMs, suppliers inevitably suffer by losing economies of scale, hence studying the effects at all levels of the supply chain is key. Furthermore, the effect of information systems may moderate the positive impact of supplier parks, supporting the work of Wafa et al., (1996) de-linking the need for proximity in JIT systems. 
An important learning outcome for practitioners highlights the issue of where supplier parks have not fulfilled their promise to support build-to-order. Managers at these supplier parks need to focus on: 1) whether there is demand for flexibility in the first place, 2) the site is not simply a convenient use of spare capacity, and 3) where there is genuine demand for build-to-order, is there adequate support from top management? Supplier parks with the potential for BTO need to

build scale by encouraging suppliers to locate with appropriate levels of asset specificity managed through trust-based, obligational supplier relationships (Sako, 1990). Only by considering the supplier park in the context of a long-term vision and as part of a dedicated strategy towards building to order can VMs and suppliers expect to realise superior levels of performance.

\section{Bibliography}

Baldwin, C. Y., \& Clark, K. B. 1997. Managing in an age of modularity. Harvard Business Review, 75(5): 84-93.

Berry, W., \& Cooper, M. 1999. Manufacturing flexibility: methods for measuring the impact of product variety on performance. Journal of Operations Management, 17(2): 163-179.

Checkland, P. 1991. From Framework through Experience to Learning: the essential nature of Action Research. In H. Nissen, H. Klein, \& Hirscheim (Eds.), Information Systems Research: Elsevier Science.

Chew, E. 2003. Carmakers reap benefits of supplier park concept, Automotive News Europe, Vol. 8: 21.

Collins, R., Bechler, K., \& Pires, S. 1997. Outsourcing in the Automotive Industry: From JIT to Modular Consortia. European Management Journal, 15(5): 498-508.

Cullen, T. 2002. Carmakers split on supplier parks, Automotive News Europe, Vol. 7: 26.

Davis, C. 2005. Inside Dell's manufacturing facility. Supply Chain Europe, 14(1): 34-35.

DiMaggio, P., \& Powell, W. W. 1991. The New Institutionalism in Organizational Analysis. Chicago: The University of Chicago Press.

Doran, D. 2001. Synchronous supply: an automotive case study. European Business Review, 13(2): 114-120.

Doran, D. 2003. Supply chain implications modularization. International Journal of Operations \& Production Management, 23(3): 316-326.

Dubois, A., \& Gadde, L. 2002. Systematic combining: an abductive approach to case research. Journal of Business Research, 55: 553-560.

Dyer, J. H. 1996. Specialized supplier networks as a source of competitive advantage: evidence from the auto industry. Strategic Management Journal, 17(4): 271-291.

Dyer, J. H., \& Singh, H. 1998. The relational view: cooperative strategy and sources of interorganizational competitive advantage. Academy of Management Review, 24(4): 660-679.

Eisenhardt, K. M. 1989. Building Theory from Case Study Research. Academy of Management Review, 14(4): 532-550. 
Ferdows, K., Lewis, M., \& Machuca, J. A. D. 2003. Zara. Supply Chain Forum, 4(2): 62-67.

Fisher, M. L. 1997. What is the Right Supply Chain for your Product? Harvard Business Review, 75, March-April(2): 105-116.

Fredriksson, P. 2002. Modular assembly in the car industry - an analysis of organizational forms' influence on performance. European Journal of Purchasing and Supply Management, 8: $221-233$

Gunasekaran. 2005. Build-to-order supply chain management: a literature review and framework for development. Journal of Operations Management, 23: 423-451.

Holweg, M., \& Greenwood, A. 2001. Product Variety, Life Cycles and Rate of Innovation Trends in the UK Automotive Industry, World Automotive Manufacturing: 12-16. London.

Holweg, M., \& Miemczyk, J. 2002. Logistics in the "three-day car" age: assessing the responsiveness of vehicle distribution logistics in the UK. International Journal of Physical Distribution and Logistics Management, 32(10): 829-850.

Holweg, M., \& Pil, F. K. 2001. Successful Build-to-Order Strategies start with the Customer. Sloan Management Review(Fall): 74-83.

Holweg, M., \& Pil, F. K. 2004. The Second Century: Reconnecting Customers and Value Chain through Build-to-Order. Cambridge, Massachusetts: The MIT Press.

Howard, M., Vidgen, R., \& Powell, P. 2003. Overcoming stakeholder barriers in the automotive industry. Journal of Information Technology, 18(1): 27-43.

Hsuan, J. 1999. Impacts of supplier-buyer relationships on modularization in new product development. European Journal of Purchasing and Supply Management, 5: 197-209.

Jack, E., \& Raturi, A. 2002. Sources of volume flexibility and their impact on performance. Journal of Operations Management, 20(5): 519-549.

Kast, F. E., \& Rosenzweig, J. E. 1981. Organization and Management - A Systems and Contingency Approach (3rd Edition ed.). London: McGraw Hill.

Klein, B., Crawford, R., \& Alchian, A. 1986. Vertical integration, appropriable rents and competitive contracting process. In R. Kroszner (Ed.), The Economic Nature of the Firm.

Kochan, A. 2002. Lean production helps logistics firms, Automotive News Europe, Vol. 7: 8.

Larsson, A. 2002. The Development and Regional Significance of the Automotive Industry: Supplier Parks in Western Europe. International Journal of Urban and Regional Research, 26(4): 767-784.

Marinin, K. J., \& Davis, T. R. V. 2002. Modular assembly in international automotive manufacturing. International Journal of Automotive Technology Management, 2(3/4): 353-362.

Marshall, C., \& Rossman, B. G. 1989. Designing Qualitative Research. CA: Sage Publications.

Miemczyk, J., Howard, M., \& Graves, A. 2004. Supplier Parks in the European Auto Industry. Paper presented at the 11th European Operations Management Association International Conference, Insead, France.

Miles, M., \& Huberman, A. 1994. An Expanded Sourcebook: Qualitative Data Analysis. Thousand Oaks, CA: Sage.

Millington, A. I., Millington, C. E. S., \& Cowburn, M. 1998. Local assembly units in the motor components industry. International Journal of Operations and Production Management, 18(2): 180-194.

Sako, M. 1990. Prices, Quality and Trust: Inter-firm relations in Britain and Japan. Cambridge: Cambridge University press.

Sako, M., \& Murray, F. 1999a. Modules in Design, production and Use: IMplications for the global automotive industry, paper prepared for the IMVP Annual Forum. Boston, MIT. 
Sako, M., \& Warburton, M. 1999b. Modularization and outsourcing project: Preliminary Report of the European Research Team, paper prepared for the IMVP Annual Forum. Boston MIT.

Salvador, F., Forza, C., \& Rungtusanatham, M. 2002. Modularity, product variety, production volume, and component sourcing: theorizing beyond generic prescriptions. Journal of Operations Management, 20(5): 549-576.

Sanchez, R., \& Mahoney, J. T. 1996. Modularity, Flexibility, and Knowledge Management in Product and Organization Design. Strategic Management Journal, 17 (Winter special issue): 63-76.

Saxenian, A. 1994. Regional Advantage. Cambridge, MA: Harvard University Press.

Schonberger, R. J., \& Gilbert, J. P. 1983. Just-In-Time Purchasing: A challenge for U.S. Industry. California Management Review, 1(Fall): 54-68.

Shah, R., \& Ward, P. 2003. Lean manufacturing: context, practice bundles and performance. Journal of Operations Management, 21(2): 129-150.

Slack, N. 1991. The Manufacturing Advantage. London: Mercury Books.

Stuart, I., McCutcheon, D., Handfield, R. B., McLachlin, R., \& Samson, D. 2002. Effective case research in operations management: a process perspective. Journal of Operations Management, 20(5): 419-433.

Svensson, G. 2000. A conceptual framework for the analysis of vulnerability in supply chains. International Journal of Physical Distribution and Logistics Management, 30(9): 731749.

Upton, D. 1994. The Management of Manufacturing Flexibility. California Management Review, 36(2): 72.

Von Corswant, F., \& Fredriksson, P. 2002. Sourcing trends in the car industry. International Journal of Operations \& Production Management, 22(7): 741-758.

Voss, C., Tsikriktsis, N., \& Frohlich, M. 2002. Case Research in Operations Management. International Journal of Operations and Production Management, 22(2): 195-219.

Wafa, M. A., Yasin, M. M., \& Swinehart, K. 1996. The impact of supplier proximity in JIT success: an informational perspective. International Journal of Physical Distribution and Logistics Management, 26(4): 23-34.

Ward, P. T., \& Duray, R. 2000. Manufacturing strategy in context:environment, competitive strategy and manufacturing strategy. Journal of Operations Management, 18(2): 123138.

Williamson, O. E. 1979. Transaction-Cost Economics: The Governance of Contractual Relations. Journal of Law and Economics, 22(2): 233-261.

Yin, R. K. 1994. Case Study Research: Design and Methods (2nd ed.). Thousand Oaks: Sage Publishing. 


\section{Appendix A - Case study suppliers and products supplied}

\begin{tabular}{|c|c|c|}
\hline Case & Suppliers & Product/s supplied \\
\hline \multirow{11}{*}{ Seat, Abrera } & Benteler, & Axles \\
\hline & Cristaleria & Glass \\
\hline & Expert & $\begin{array}{l}\text { Brake sub-assembly, Sub-frame, driveshaft, ECU, } \\
\text { fuel pump }\end{array}$ \\
\hline & Johnson controls & Front end, steering column \\
\hline & kautex textron & Fuel tanks \\
\hline & lignotock & Panels \\
\hline & Monroe & Shock absorber \\
\hline & SiemensVDO & Cockpit \\
\hline & TRW & Unicables, Yazaki \\
\hline & Sylea & Wiring \\
\hline & $\begin{array}{l}\text { Ace, Antolin Irausa, Arvin, } \\
\text { Borgers, Bosal, Delphi, } \\
\text { Emisint, Galvaplast, Inducar, } \\
\text { Magneti Marelli, Mai, } \\
\text { Pertersa, Perti, Sivesa }\end{array}$ & Various others including exhausts \\
\hline Ford, Bridgend & In early development phase & $\begin{array}{l}\text { Logistics services and basic components ('nuts and } \\
\text { bolts') }\end{array}$ \\
\hline \multirow[t]{4}{*}{ Ellesmere Port } & Delphi & $\begin{array}{l}\text { Cruise control, generators, steering wheels, audio } \\
\text { systems, a/c modules, compressors, wiring systems, } \\
\text { suspension modules, power brakes, front subframe }\end{array}$ \\
\hline & Plastic Omnium & Bumpers, fog lights \\
\hline & Inergy & Fuel tanks, filler systems \\
\hline & Mackie/Ryder & $\begin{array}{l}\text { Logistics and assembly, interior trim, cooling } \\
\text { modules }\end{array}$ \\
\hline \multirow[t]{16}{*}{ Volvo, Gent } & Faurecia & Dashboards / Cockpit \\
\hline & Rieter & Floor mats / carpets \\
\hline & ECA & Seats \\
\hline & MCS & Wheels and tires \\
\hline & Lear & Interior parts \\
\hline & JCI & Head lining and tunnel console \\
\hline & Plastal & Bumpers \\
\hline & Tennaco & Exhaust systems \\
\hline & Autoliv & Steering Wheel and airbags \\
\hline & Delphi & Cable Harness \\
\hline & Inoplast & Tailgates \\
\hline & Borgens & Hat-shelf \\
\hline & Sekurit & Windows \\
\hline & TI Group & Fuel tanks \\
\hline & CLG & Wheel suspension system \\
\hline & ECT & Powerpack, \\
\hline \multirow[t]{7}{*}{ Jaguar, Halewood } & FX Coughlin & Logistics services \\
\hline & Conix & Front and rear bumper \\
\hline & Visteon & $\begin{array}{l}\text { Instrument panel assembly, cooling modules, centre } \\
\text { console }\end{array}$ \\
\hline & Stadco & Body construction subassemblies \\
\hline & JCI & Interior and trim components \\
\hline & Lear & Seats, harnesses (wiring looms) \\
\hline & Infast & Fasteners, hardware \\
\hline \multirow[t]{7}{*}{ Audi, Ingolstadt } & Dräxlmaier & Wiring harness/dashboard \\
\hline & Delphi & Interior wiring harness \\
\hline & Faurecia & Front end \\
\hline & Seeber, & Interior door linings \\
\hline & SiemensVDO & Fuel tank assembly \\
\hline & Kautex & Fuel tank assembly \\
\hline & Montes & Air Filter/Centre Consoles \\
\hline
\end{tabular}




\begin{tabular}{|l|l|l|}
\hline \multirow{4}{*}{$\begin{array}{l}\text { LG Rover, } \\
\text { Longbridge }\end{array}$} & Illbruck & Door Insulation \\
\cline { 2 - 3 } & Rehau & Bumper module \\
\cline { 2 - 3 } & Peguform & Door lining/bumper module \\
\cline { 2 - 3 } & VW Braunschweig & Suspension module \\
\hline Volvo, Torslanda & Johnson Controls & Instrument panels/fascia \\
\cline { 2 - 3 } & Plastic Omnium & Front and rear bumpers \\
\cline { 2 - 3 } & Sommer Allibert & Headliners \\
\cline { 2 - 3 } & JCI & Head lining/tunnel console \\
\cline { 2 - 3 } & Lear & Seats, \\
\cline { 2 - 3 } & Plastal & Bumpers \\
\cline { 2 - 3 } & Tennaco & Exhaust systems \\
\cline { 2 - 3 } & Faurecia & Cockpit \\
\cline { 2 - 3 } & Autoliv & Steering wheels and airbags \\
\cline { 2 - 3 } & CLG & Wheel suspension system \\
\cline { 2 - 3 } & ECT & Powerpack \\
\cline { 2 - 3 } & MCS & Wheels \\
\cline { 2 - 3 } & TI Group & Fuel tanks \\
\cline { 2 - 3 } & Sekurit & Windows \\
\cline { 2 - 3 } & Rieter & Carpets \\
\cline { 2 - 3 } & Delphi & Cable Harness \\
\cline { 2 - 3 } & Scheren \& Trien & Roof mouldings \\
\cline { 2 - 3 } & Inoplast & Tailgates \\
\hline & Borgens & Hatshelf \\
\hline & & \\
\hline
\end{tabular}




\section{Appendix B - Case Study Protocol}

\subsection{Case selection criteria}

Age: recent and more established parks i.e between 0 and 10 years

Size: large (10 suppliers or over) and small (less than 10 suppliers) parks

OEM activity: volume vehicle assembly, premium vehicle assembly and engine manufacture Drivers for the Supplier park development: Mix or volume flexibility requirements, funding incentives

\subsection{Interview schedule}

General information: When was plant opened? When was last model change? How many models produced? What is annual production target? What are body styles and variants? Describe other production variables.

Information on suppliers on park: location, date of development, components produced, union membership, nature of infrastructure, cost of development and source of funding, area of site, responsibilities, training, information and knowledge sharing.

Operations and logistics: mode of transport, frequency of delivery, delivery performance, level of inventory, roles and responsibilities.

Information flow: types of information systems, frequency and time horizons, information variability and reliability.

What are the factors that influence decision to locate a supplier on the park? Follow conceptual model items.

What are the benefits of supplier parks?

\subsection{Site visit procedure}

- Tour of supplier park and facilities.

- Tour of vehicle assembly plant and specifically inbound logistics operations to line-side.

- Interviews with supplier park managers and materials, planning and logistics managers. 


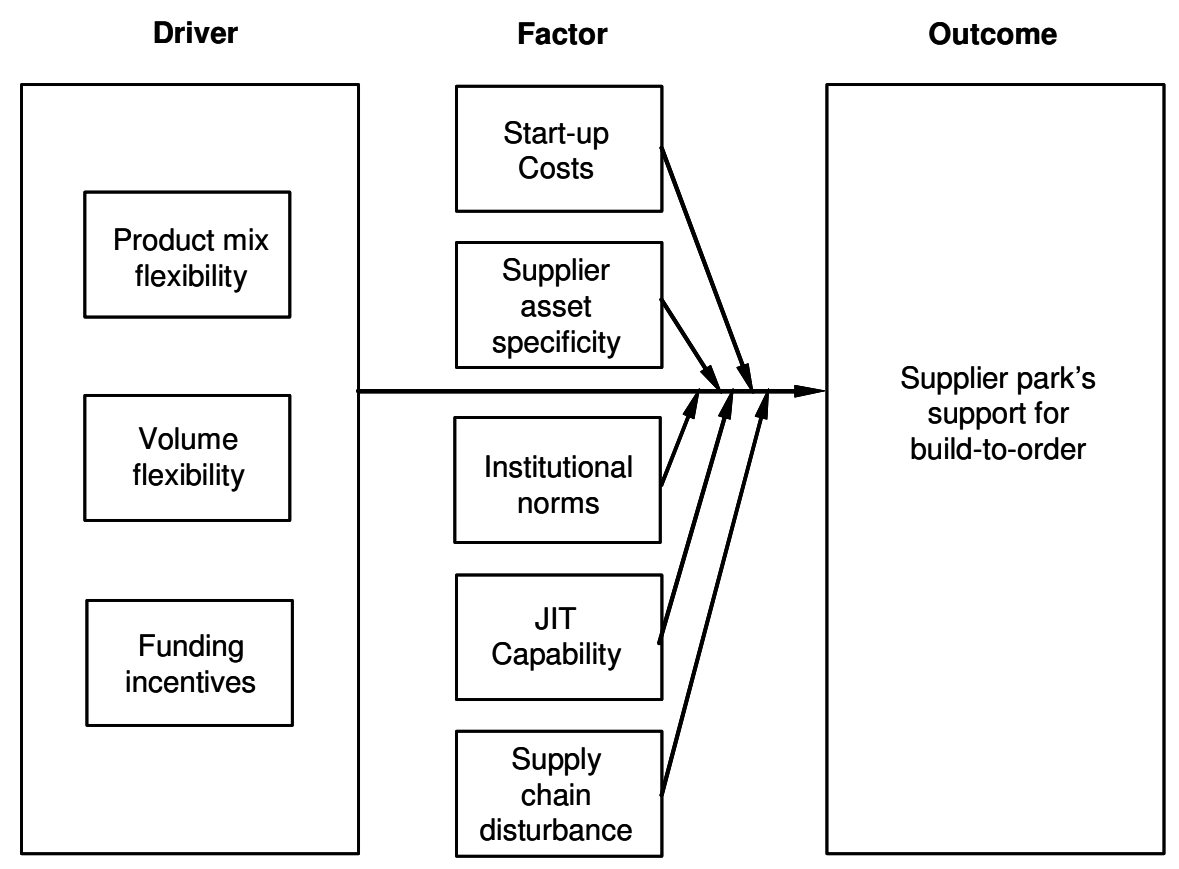

Figure 1 Conceptual framework: drivers, moderating factors, and outcome 


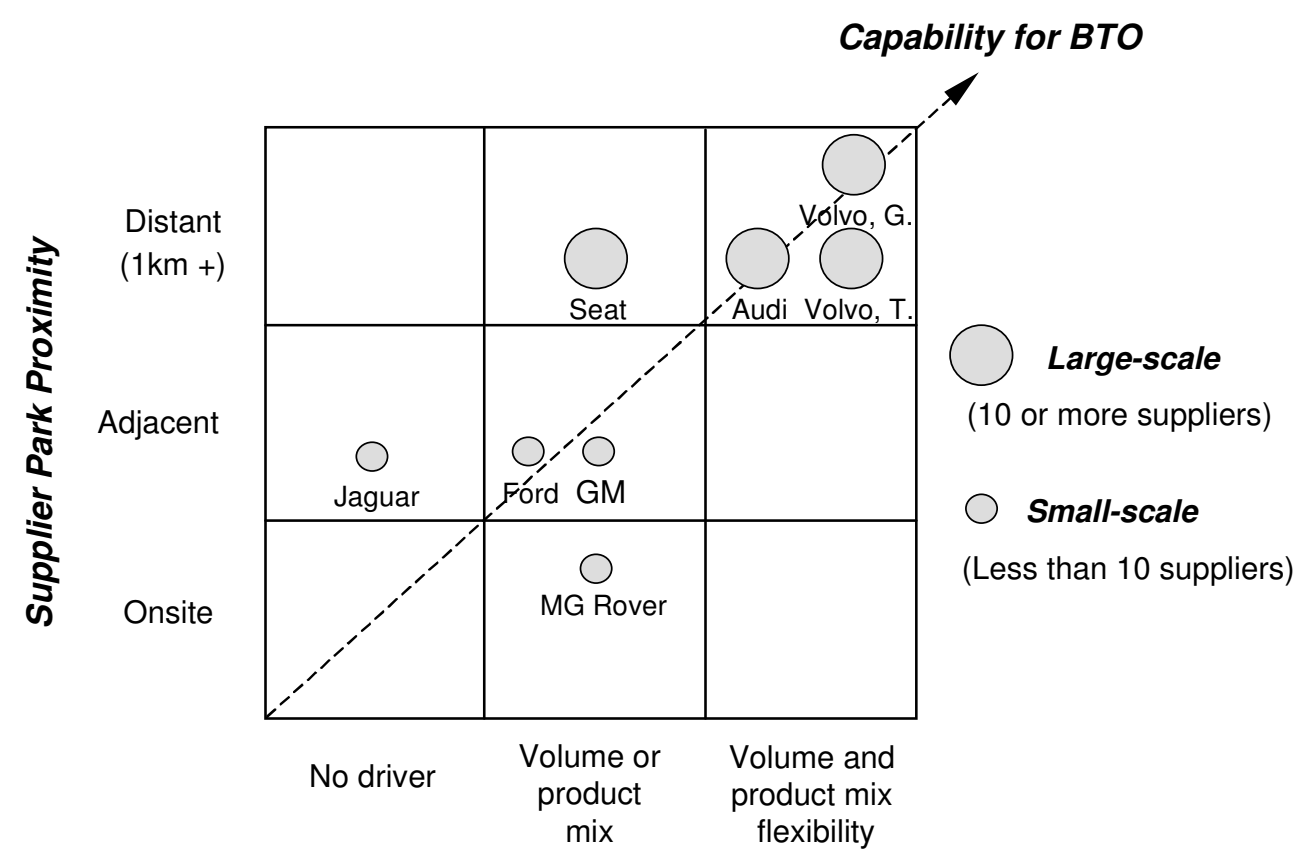

\section{Strategic BTO flexibility}

Figure 2 The role of supplier parks for build-to-order 


\begin{tabular}{|c|l|l|l|c|c|c|}
\hline Case & \multicolumn{1}{|c|}{ Organization / location } & Drivers & Other characteristics & \multicolumn{1}{c|}{$\begin{array}{c}\text { No. } \\
\text { visits }\end{array}$} & $\begin{array}{c}\text { No. } \\
\text { interviews } \\
\text { visit }\end{array}$ \\
\hline 1 & Seat / Exel Logistics, Abrera, Spain & $\begin{array}{c}\text { Government } \\
\text { funding }\end{array}$ & Volume manufacturer & 2 & 5 & $24 / 4 / 02$ \\
\hline 2 & Ford Motor Co Ltd, Bridgend, UK & Product mix & Volume manufacturer & 3 & 3 & $14 / 2 / 02$ \\
\hline 3 & General Motors, Ellesmere Port, UK & Product mix & Volume manufacturer & 4 & 6 & $20 / 3 / 01$ \\
\hline 4 & Volvo Car Corp, Gent, Belgium & $\begin{array}{c}\text { Prod/Vol flex. } \\
\text { Gov't funding }\end{array}$ & Premium manufacturer & 1 & 2 & $15 / 5 / 02$ \\
\hline 5 & Jaguar Cars Ltd, Halewood, UK & Gov't funding & Premium manufacturer & 1 & 2 & $26 / 5 / 02$ \\
\hline 6 & Audi AG, Ingolstadt, Germany & Gov't funding & Premium manufacturer & 1 & 2 & $21 / 2 / 02$ \\
\hline 7 & MG Rover Group, Longbridge, UK & Volume flex. & Volume manufacturer & 3 & 6 & $14 / 3 / 01$ \\
\hline 8 & Volvo Car Corp, Torslanda, Sweden & Prod./Vol. flex. & Premium manufacturer & 2 & 4 & $21 / 3 / 02$ \\
\hline
\end{tabular}

Table 1 Rationale for the selection of supplier parks visited during this research

\begin{tabular}{|c|c|c|c|c|c|c|c|c|}
\hline & $\begin{array}{c}\text { Seat } \\
\text { Abrera }\end{array}$ & $\begin{array}{c}\text { Ford } \\
\text { Bridgend }\end{array}$ & $\begin{array}{c}\text { GM } \\
\text { Ellesmere }\end{array}$ & $\begin{array}{l}\text { Volvo } \\
\text { Gent }\end{array}$ & $\begin{array}{c}\text { Jaguar } \\
\text { Halewood }\end{array}$ & $\begin{array}{c}\text { Audii } \\
\text { Ingolstadt }\end{array}$ & $\begin{array}{l}\text { MG Rover } \\
\text { Longbridge }\end{array}$ & $\begin{array}{c}\text { Volvo } \\
\text { Torslanda }\end{array}$ \\
\hline $\begin{array}{l}\text { Number of } \\
\text { suppliers }\end{array}$ & 32 & 1 & 4 & 15 & 6 & 11 & 3 & 15 \\
\hline $\begin{array}{l}\text { Number of } \\
\text { models }\end{array}$ & 6 & 3 & 2 & 2 & 1 & 2 & 4 & 4 \\
\hline $\begin{array}{l}\text { Distance to } \\
\text { OEM (kms) }\end{array}$ & 2.5 & 0.5 & 1 & 3 & 0.5 & 0.5 & 0 & 3 \\
\hline Volume (pa) & 426,675 & $1,075,000$ & 350,000 & 160,000 & 55,610 & 308,594 & 163,144 & 170,000 \\
\hline Age (yrs) & 10 & 1 & 3 & 3 & 4 & 6 & 2 & 4 \\
\hline Country & Spain & UK & UK & Belgium & UK & Germany & UK & Sweden \\
\hline
\end{tabular}

Table 2 Supplier park case statistics 


\begin{tabular}{|c|c|c|c|}
\hline Case & Drivers & Factors & Outcome \\
\hline $\begin{array}{l}\text { Volvo } \\
\text { Torslanda }\end{array}$ & $\begin{array}{l}\text { - Product mix flexibility } \\
\text { - Volume flexibility }\end{array}$ & $\begin{array}{l}\text { - } \text { Low start up costs } \\
\text { - } \text { Risk of strategic } \\
\text { inflexibility } \\
\text { - } 80 \% \text { of supplied value } \\
\text { delivered by SILS }\end{array}$ & $\begin{array}{l}\text { - A large-scale distant } \\
\text { supplier park critical to } \\
\text { sustain BTO } \\
\text { - } \begin{array}{l}\text { Inflexibility ameliorated by } \\
\text { obligational contractual } \\
\text { relationships }\end{array}\end{array}$ \\
\hline $\begin{array}{l}\text { Volvo } \\
\text { Gent }\end{array}$ & $\begin{array}{l}\text { - Product mix flexibility } \\
\text { - Volume flexibility }\end{array}$ & $\begin{array}{ll}\text { - } & \text { Low start up costs } \\
\text { - } & \text { Risk of strategic } \\
\text { inflexibility } \\
\text { - } \\
\text { 80\% of supplied value } \\
\text { delivered by SILS }\end{array}$ & $\begin{array}{ll}\text { - } & \text { A large-scale distant } \\
\text { supplier park critical to } \\
\text { sustain BTO } \\
\text { - } \\
\text { Inflexibility ameliorated by } \\
\text { obligational contractual } \\
\text { relationships }\end{array}$ \\
\hline $\begin{array}{l}\text { Seat } \\
\text { Abrera }\end{array}$ & $\begin{array}{l}\text { - Product mix flexibility } \\
\text { - Volume flexibility }\end{array}$ & $\begin{array}{l}\text { - } \text { Low start up costs } \\
\text { - Low asset specificity } \\
\text { - Union resistance } \\
\text { - JIT capability held by } \\
\text { third party provider } \\
\text { - Distance allows capacity } \\
\text { flexibility }\end{array}$ & $\begin{array}{l}\text { A large-scale distant third } \\
\text { party controlled supplier } \\
\text { park } \\
\text { - Separate location from the } \\
\text { OEM assembly plant means } \\
\text { capacity can be expanded }\end{array}$ \\
\hline $\begin{array}{l}\text { Audi } \\
\text { Ingolstadt }\end{array}$ & $\begin{array}{l}\text { - Public funding } \\
\text { - Product mix flexibility } \\
\text { - Volume flexibility }\end{array}$ & $\begin{array}{l}\text { - Low start up costs } \\
\text { - Personnel and plant asset } \\
\text { specificity } \\
\text { - Union resistance } \\
\text { - JIT capability held by } \\
\text { OEM }\end{array}$ & $\begin{array}{l}\text { A large scale adjacent } \\
\text { supplier park that addresses } \\
\text { the recent increase in } \\
\text { component variants and } \\
\text { volume } \\
\text { - Core role in both reducing } \\
\text { logistics costs and } \\
\text { overcoming capacity } \\
\text { constraints }\end{array}$ \\
\hline $\begin{array}{l}\text { Jaguar } \\
\text { Halewood }\end{array}$ & $\begin{array}{l}\text { - Public funding } \\
\text { - Volume flexibility - } \\
\text { (reduced during development) }\end{array}$ & $\begin{array}{l}\text { - Low start up costs } \\
\text { - Union resistance to } \\
\text { - JIT capability held by } \\
\text { OEM, but long call-off } \\
\text { leadtime }\end{array}$ & $\begin{array}{l}\text { A large scale, mixed use } \\
\text { industry park, the result of a } \\
\text { change in manufacturing } \\
\text { strategy by Ford Europe } \\
\text { - No drivers for BTO, hence } \\
\text { no benefits }\end{array}$ \\
\hline $\begin{array}{l}\text { MG Rover } \\
\text { Longbridge }\end{array}$ & $\begin{array}{l}\text { - Product mix flexibility } \\
\text { - Volume flexibility - } \\
\text { (reduced during development) }\end{array}$ & 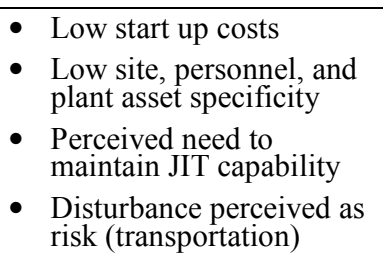 & $\begin{array}{l}\text { A small-scale, on-site } \\
\text { dedicated supplier park } \\
\text { capable of supporting BTO } \\
\text { - } \begin{array}{l}\text { Insufficient number of } \\
\text { suppliers to enable BTO }\end{array} \\
\text { - } \begin{array}{l}\text { Reduction in overall } \\
\text { production volume means } \\
\text { BTO is low priority }\end{array}\end{array}$ \\
\hline $\begin{array}{l}\text { GM } \\
\text { Ellesmere } \\
\text { Port }\end{array}$ & - Volume flexibility & 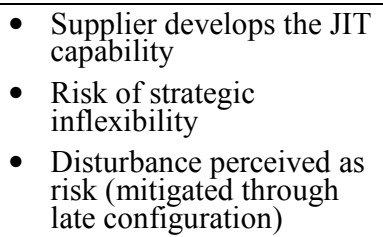 & $\begin{array}{l}\text { A small-scale, adjacent } \\
\text { supplier park capable of } \\
\text { limited support by } \\
\text { minimising the effects of } \\
\text { SC disturbance through late } \\
\text { configuration }\end{array}$ \\
\hline $\begin{array}{l}\text { Ford } \\
\text { Bridgend }\end{array}$ & $\begin{array}{l}\text { - Public funding } \\
\text { - Product mix flexibility }\end{array}$ & $\begin{array}{ll}\text { - } & \text { Low start up costs } \\
\text { - } & \text { High asset specificity for } \\
\text { suppliers (primary } \\
\text { manufacturing) } \\
\text { - } \\
\text { Replicating industry best } \\
\text { practice on SP } \\
\text { - JIT capability held by } \\
\text { OEM } \\
\text { - } \begin{array}{l}\text { Disturbance perceived as } \\
\text { risk (transportation) }\end{array}\end{array}$ & $\begin{array}{l}\text { A small-scale shared } \\
\text { industry park with one } \\
\text { supplier and one logistics } \\
\text { provider (low level specific } \\
\text { assets to Ford) despite the } \\
\text { prospect for supporting } \\
\text { BTO }\end{array}$ \\
\hline
\end{tabular}


Table 3 Cross-case analysis of the drivers and factors affecting supplier park outcome 